\title{
AMANDA GREENWOOD: EDNA O'BRIEN, TAVISTOCK, NORTHCOTE HOUSE, 2003, 137 pp.
}

\author{
$M^{a}$ ÁNGELES POZO MONTAÑO \\ University of North Carolina, Chapel Hill (USA)/Universidad de Sevilla
}

Greenwood's book about Edna O'Brien belongs to the new series of Northcote House in collaboration with the British Council called Irish Writers and Their Work. This critical work fills a gap of nearly thirty years, when the first book about Edna O'Brien and her work was published. O'Brien's prolific writing is a fertile land to explore. However, even though she has been widely studied by scholars, it is surprising that only two books about her writing have been published so far.

The book that foreruns Greenwood's is also called Edna O'Brien by Grace Eckley (1974) ${ }^{1}$. In her critical work Eckley analyzed O'Brien's fiction according to 1970s Anglo-American feminism. In her short book Eckley talks about O'Brien's «Personal Odyssey», which is a review of O'Brien's works up to her novel Night (1972). Eckley also studies O'Brien's portrayal of women in her chapters "Cinderella in Daylight, or Feminism and Shattered Shibboleths» and "Guilt by Inheritance.» Finally, Eckley devotes a last chapter to the connection between O'Brien's fiction and James Joyce's. Greenwood also sets forth feminist theories, namely those of Simone de Beauvoir, Luce Irigaray, Hélene Cixous and Toril Moi. Throughout the nine chapters in which the book is organized, Greenwood explores issues in O'Brien's fiction such as "femininity", "masculinity», and "Irishness», but above all, she draws from all that the basics to discover O'Brien's persona. From the vast list of O'Brien's works, Greenwood touches on twelve novels, one biography, one collection of short stories and one play.

In the first chapter, Greenwood ponders about how O'Brien is regarded in the press and how these commentaries have contributed to a constructed public opinion of O'Brian based on a polarized identity. In the first place, she pays attention to the duality of O'Brien's persona, which seems to be stuck in biased categorizations. Her first novels won her acclaim for her sentimental

1. Eckley, Grace: Edna O'Brien, Lewisburg, Bucknell UP, 1974. 
writing. This fact, along with the semi-autobiographical character of her narrative created the preconception about O'Brien as a femme fatale. In keeping with this idea, Greenwood observes that O'Brien's good looks and some of her social interaction have undermined to a certain extent her position as a serious writer. Therefore, even though O'Brien has been working on other thematic fields, such as that of politics, she has found it difficult to free herself from the partiality of critics. An important landmark in O'Brien's criticism was the publication of a special edition of the Canadian Journal of Irish Studies $(C J I S)^{2}$ in 1996, which contained eight essays written from a wide range of theoretical perspectives.

The following chapter discusses the historical and literary construction of Ireland and the Irish woman under the masculine gaze. Ireland has been traditionally considered a woman and the Irish woman has found it difficult to liberate herself from the roles of muse and mate. The outline of O'Brien's persona encounters this problematization because she fulfills what is expected of an Irish colleen but at the same time she resists and subverts masculine definitions.

Chapter 3 enrolls in the task of proving how some of O'Brien's most conventional feminine Irish books are subversive and deconstruct such notions as "femininity» and "Irishness». These books are The Country Girls trilogy, August is a Wicked Month (1965), Casualties of Peace (1966), and the short story collection The Love Object (1968). Greenwood denominates The Country Girls trilogy a "negative romance», expression that indicates "fiction which examines the condition of women under patriarchy by subverting "romance» while conforming superficially to the genre» (23). O'Brien destabilizes the protagonist's romantic and naïve expectations with the juxtaposition of her worldly loved men. Apart from the gap established between the protagonist and her lovers these books are filled with images that undermine the concept of "romance». August is a Wicked Month, Casualties of Peace, and The Love Object also destabilize the notion of «romance» by making the protagonists fluctuate between romance and reality.

The fourth chapter deals with the novels A Pagan Place (1970) and Night (1972). The analysis of both novels is tackled under the perspective of écriture feminine. Confronting the protagonists' writing with the body, there is the masculine dominance within the texts, especially the discourse of "fathers," namely biological, literary and religious fathers.

Mother Ireland (1976) and Virginia (1981) are objects for discussion in the fifth chapter. Greenwood initiates her analysis of Mother Ireland with Toril Moi's assertion that autobiographical texts of an author need to be read "with and against each other in order to bring out their points of tension, contradictions and similarities» (50). Regarding O'Brien's autobiographical work, Mother Ireland, Greenwood addresses the question of how the writer's identity is shadowed by her literary father James Joyce and constructed by a colonized

2. Schrank, Bernice (ed.): Canadian Journal of Irish Studies, 22.2 (1996). 
notion of "Irishness.» As Greenwood explains O'Brien also creates her identity on a parallel with her country from the moment she establishes «the land itself» as the point of departure for her narrative. Greenwood explores the play Virginia considering it «an attempt to unite the fractured identities of two women writers» (59). Although belonging to different historical contexts, both writers fuse in this play to give voice to O'Brien's concern with creating a social and symbolic order "constructed according to the feminine» (62).

Chapter 6 readdresses the topic of female subjectivity in O'Brien's novel The High Road (1988). As in previous novels women are regarded in The High Road as commodities entrapped in the patriarchal symbolic order and values that construct their identities. The lesbian relationship between the protagonists and the recurrent imagery of fluids offer manifold interpretations. At the same time that they seem to vindicate for a maternal imaginary, both the lesbian bond and the metaphors of fluids have inconsistent meanings since they are also constructed within male references.

In the 1990's O'Brien turned her interests towards Irish social problems. She published her political trilogy drawn from issues that had befallen contemporary Ireland. House of Splendid Isolation (1994), Down by the River (1996) and Wild Decembers (1999) encompass the problems of terrorism, abortion and land ownership. According to Greenwood, O'Brien deconstructs «masculinity» as well as "femininity» throughout the trilogy.

Chapter 8 accounts for O'Brien's devotion to her literary father, James Joyce. Her commitment to Joyce culminated with the publication of her biography in 1999. Greenwood reacts against negative critics that followed the book and she defends O'Brien's authority to portray the life of his master. Greenwood analyzes O'Brien's biography according to notions of feminine and masculine constructions, what makes her establish parallels between O'Brien's comments on Joyce and feminist theory. She also introduces O'Brien's own fictional works to show how they answer both Joyce's life and his works, thus illustrating the influence of her literary father in her career.

It is a risky thing to write a book about a writer who is alive, especially when she is a fruitful writer. The latent problem of a book belonging to such an author emerges in Greenwood's work when the reader finds out two conclusions. Edna O'Brien is such a prolific writer that when it comes to commenting on her work one is never sure whether she has written something new in the last few months. Greenwood initially finished her book in chapter 8, dedicating it to the remaining and predictable topic about O'Brien and Joyce. At the same time this closing provided her book a structure that paralleled the last chapter of Eckley's manuscript. But this ending was truncated by the publication of one of O'Brien's most polemic books, In The Forest (2002). Even though her script had been already copied and edited, Greenwood felt the need to include another chapter commenting this novel and supporting O'Brien and her agent, David Godwin, on the integrity of the controversial book. Nevertheless, irrespective of Greenwood's attempt to make his work as complete as possible with the 
latest of O'Brien's work, only one year later, the publication of O'Brien's play Iphigenia (2003) ${ }^{3}$ made Greenwood's book deficient again.

Accordingly, the last chapter explores the novel In the Forest from a feminist perspective. Greenwood draws attention to how the protagonists mirror social and symbolic constructions of masculinity and femininity. One interesting thing that she observes is the fact that O'Brien's depiction of women throughout her literary career has been constantly polarized between "Madonna» and "witch» (107).

Finally, in spite of the remarkable study that Greenwood accomplishes, there is one flow that should be revised: the bibliography of primary sources. It is hard to find a rigorous bibliography that organizes O'Brien's numerous works according to literary genres and that exhaustively includes all her work within that classification. Most bibliographies, for example, fail to mention O'Brien's craft as a writer of books for children, and these books are, as a consequence, miscellaneously arranged within other genres. The category of books for children is absent in Greenwood's bibliography, and therefore, as a result of the trespassing of genres, The Dazzle, a juvenile piece of literature is found among the novels. Another collection of tales for children called Tales for the Telling: Irish Folk and Fairy Stories is classified as a collection of short stories. Furthermore, Greenwood considers in her selected bibliography book-length non-fiction books, but she includes Arabian Days among novels.

Apart from this nuance that needed clarification, the publication of this book is applauded by readers of feminist criticism and O'Brien's writing. Greenwood travels through time and space across O'Brien's most representative works to bring together in this book, on the one hand, her rendering of such issues as gender construction and Irishness, and on the other, an approach to O'Brien's thinking. This book appears in a moment that we could consider O'Brien's boom. Her works and her persona have raised much interest from critics since she started writing, but nowadays it is especially noticeable in academia. Sometimes praised as a feminist and some others rejected as such, Edna O'Brien remains controversial. However, this book places her writing within the pantheon of feminist criticism.

3. O'Brien, Edna: Iphigenia, London, Methuen, 2003. 